\title{
Research on urban park planning countermeasures in the perspective of inclusive cities
}

\author{
Jiuyue WANG, Keimyung University, Korea \\ Soobong KIM, Keimyung University, Korea
}

\begin{abstract}
Differences in the distribution of social benefits and economic status can lead to health and power inequalities for the low-income class. Parks are a product of civil rights and an important space for urban life for the low-income class. It is important to understand the current distribution of parks in areas densely populated by low-income classes. Therefore, this paper examines the demographic characteristics and the current status of park distribution in lowincome densely populated areas from the perspective of inclusive cities. To improve the living environment of low-income classes and explore realistic policy and planning directions for realizing inclusive cities. The results of this thesis are summarized as follows. First. There are differences in demographic characteristics between areas with high concentrations of lowincome people and other areas. The physical environment also differs between areas with high concentrations of low-income people and is divided into three categories based on physical environment characteristics. Second, the park supply in Daegu is higher than the legal standard, and there is no correlation between the income and the park distribution. The distribution of parks also varies greatly within areas with high concentrations of low-income people.
\end{abstract}

\section{Keywords}

inclusive cities, park planning, low-income class

\section{Background}

Inclusive cities emphasize that everyone in the city should have equal access to public spaces (Park et al., 2019). Through urban planning and management, we aim to improve the living environment of urban residents and the overall quality of life in the city (UN-HABITAT, 2016a). However, disparities in socioeconomic status at this stage have led to inequities in the distribution of power and health resources among disadvantaged groups such as low-income classes (Sundquist et al., 2004; Penny et al., 2006). As a product of civil rights (Jacobs, 1961), parks are an important urban space and health resource in urban life (Bedimo-Rung et al., 2005). It is a public place where sports equipment (sports facilities, basketball courts, tennis courts, etc.) and recreational facilities are available free of charge to all residents (Cohen et al., 2012). The low-income class has difficulty using private health clubs due to income limitations. Therefore, the low-income class will value and use parks more. In the existing studies, when there are park areas in areas with high-income population density and a low-income population density, they are influenced by different physical environments by showing different results such as positive correlation, negative correlation, and no correlation(Maroko et al., 2009; Wen et al., 2013; Lakes et al., 2014). However, it is common for parks in areas with low-income residents to have problems such as 
poor distribution, old facilities, and poor maintenance and management, which also deter the potential for low-income strata to access the parks (Huang et al, 2020). Resistance for promoting social interaction (meeting with friends, participating in social activities, etc.) and physical health (Orsega-Smith al et. 2004; Schipperijn et al. 2017). In addition, problems are increasingly evident in terms of residential segregation and the density of low-income populations due to unequal economic status. It is important to understand the current distribution of parks in areas with dense low-income classes. In Korea, the distribution of parks in areas with a high density of low-income people is still in the research stage. Few foreign studies have focused on neighborhood parks and have mostly compared by race, ethnicity, and income. Korea is less referential as a single-race country.

From the perspective of inclusive cities, this paper elaborates the demographic characteristics and physical environment of low-income population-dense areas through existing literature. It also uses basic data to explore the current distribution of parks in areas with high concentrations of low-income people. The aim is to improve their living environment and to explore realistic policy and planning directions for achieving inclusive cities.

\section{Research design}

\subsection{Research Scope}

In this paper, a central city in the south-eastern part of the Korean peninsula is selected for this study. Daegu Metropolitan City is in the middle of Daegu Basin in the eastern part of Nakdong River. It is located at $35^{\circ} 52^{\prime} 00^{\prime \prime} \mathrm{N}$ $128^{\circ} 36^{\prime} 00^{\prime \prime} \mathrm{E}$. It has an area of 883.49 square kilometers with a total population of 2,446,144 in 2020, and with a population density of 2,769 people per square kilometer. The city is formed around Dongseong-ro and Jungang-ro, and the area is divided into 7 districts and 1 county. As one of the major industrial cities in Korea, Daegu's major industries include textiles, metallurgy, and machinery. A location map of Daegu is shown in Figure1.

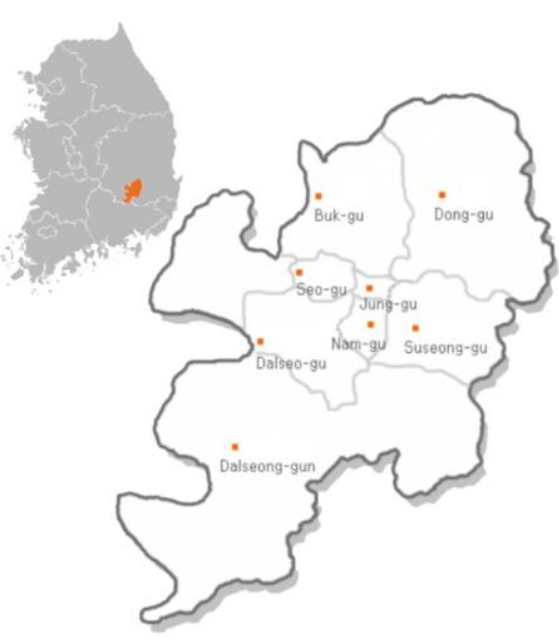

Figure 1. Location of Daegu City.

Source: drawn bv authors.

\section{2. Research Methodology}

To classify the scope of dense areas of low-income strata, four variables such as national margin obtainers, house purchase and sale prices, house rental prices, and 'living area less than $60 \mathrm{~m}^{21}$ were identified through the study of Boone et al.(2009), Kim(2015) etc .The principal component analysis used by Gordon et al. (2011) and Chen-Li (2012) in studying the spatial characteristics of cities and the distribution of dense areas of low-income people was used for dimensionality reduction. Using Clustering analysis, regions with great similarity were grouped. In this study, the 1,2 groups with the lowest values were selected and set as low-income stratum dense areas. Finally, 49 areas were selected, accounting for $35 \%$ of Daegu city as a whole. The location of the dense low-income population areas in this study is shown in red in Figure 2.

Rigolon (2016) selected park neighborhoods, park size, and park area per capita to evaluate the balance of urban parks. Therefore, in this study, we selected children's parks and neighborhood parks, which are the most constructed and most easily used in Daegu, as the study sites based on the park green space 
information of Daegu Metropolitan City. And to select the park service area first we choose the radius proximity method, and the service area of urban parks as stipulated by the Korean park law is $250 \mathrm{~m}$ for children's parks, $500 \mathrm{~m}$ for neighborhood parks below 30,000 $\mathrm{m}^{2}$, and $1000 \mathrm{~m}$ for neighborhood parks above $30,000 \mathrm{~m}^{2}$. The overall park distribution and service area of Daegu City is shown in Figure 3.

\subsection{Data sources}

The data used in this study were collected from the Korea Statistics Agency and relevant Korean government public information in the last two years, and the data were reliable and authentic. The specific sources and data time are shown in Table 1.

\section{Results}

\subsection{Demographic characteristics of low-income regions}

The characteristics of people living in the low-income densely populated areas of Daegu are analysed into three categories: demographic characteristics, household characteristics, and residential characteristics.

areas show that the population living in low-income areas, the ratio of children, the average number of households, and housing prices are much lower than the average of Daegu. On the other hand, the ratio of the elderly population and the number of people with a basic livelihood are higher than the average of Daegu(Table 2).

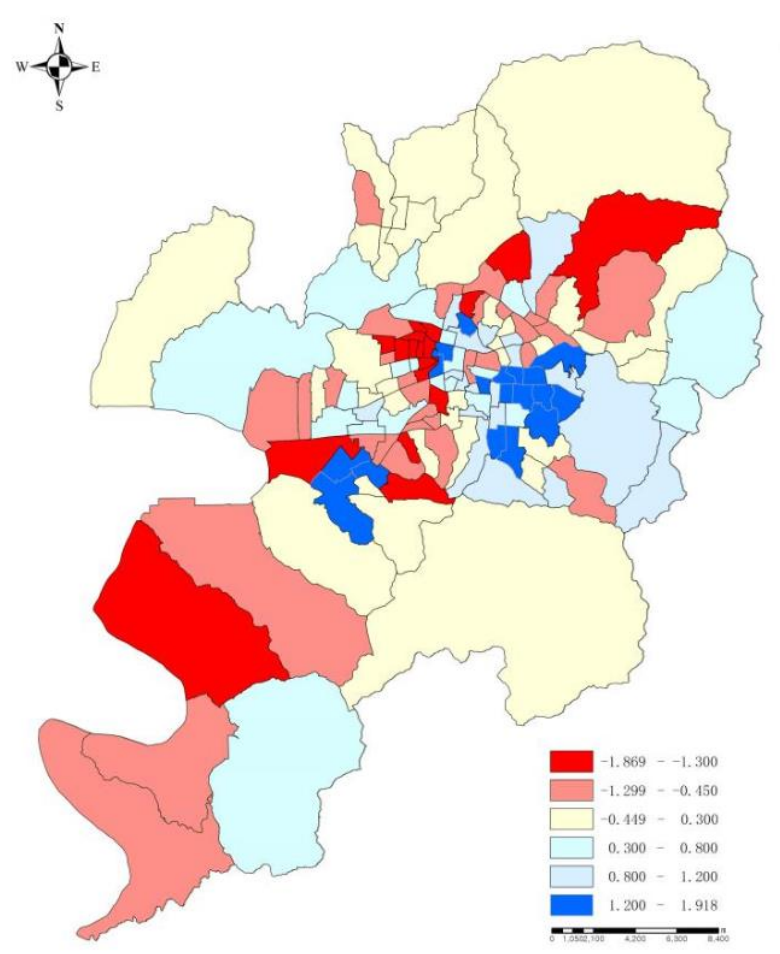

Figure 2 Estimated average income in each eup/myeon/dong in Daegu.

Source: drawn by authors.

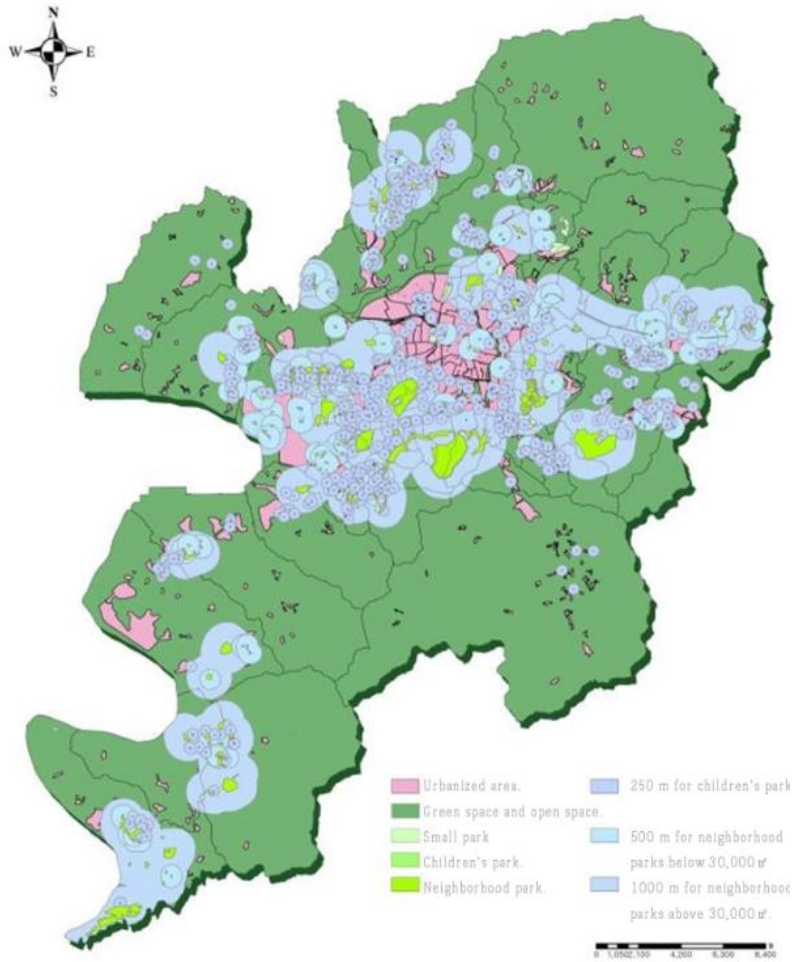

Figure 3 Daegu park area and service area.

Source: drawn bv authors. 
Wang, J.Y.; Kim, S.B.

Table 1. The specific sources and data time

\begin{tabular}{llc}
\hline Characteristic indicators & Provenance & Year \\
\hline Percentage of basic livelihood recipients & $\begin{array}{l}\text { National Statistical Office, } \\
\text { Daegu Metropolitan City. }\end{array}$ & 2020 \\
\hline Residential area $<60 \mathbf{m}^{2}$ & $\begin{array}{l}\text { The Ministry of Land, } \\
\text { Infrastructure and Transport's } \\
\text { actual transaction price } \\
\text { disclosure system. }\end{array}$ & 2020 \\
\hline Sale price per square meter & National Statistical Office & 2020 \\
\hline Jeonse price per square meter & National Statistical Office. \\
Status of administrative districts in each district and county. & 2019 \\
\hline Status of urban parks in each district and county & Daegu Statistics Office & 2020 \\
\hline Continuous theme and cadastral map & & 2020 \\
\hline Urban management plan & National Statistical Office & 2020 \\
\hline Population density & & 2020 \\
\hline Use area & & Ministry of Environment \\
\hline Local slope & & 2020
\end{tabular}

Table 2. Demographic characteristics of low-income regions

\begin{tabular}{|c|c|c|c|c|}
\hline & Characteristic indicators & $\begin{array}{l}\text { low-income } \\
\text { areas. }\end{array}$ & $\begin{array}{l}\text { The average } \\
\text { in Daegu. }\end{array}$ & $\begin{array}{l}\text { High-income } \\
\text { areas }\end{array}$ \\
\hline \multirow[t]{7}{*}{ Population } & Number of people** & 12386 & 17497 & 18739 \\
\hline & Number of elderly people* & 2510 & 2826 & 2726 \\
\hline & $\begin{array}{l}\text { The proportion of the elderly } \\
\text { population** }\end{array}$ & $22.5 \%$ & $19.3 \%$ & $16.7 \%$ \\
\hline & The number of children...** & 1436 & 2924 & 3787 \\
\hline & Percentage of children's population** & $10.6 \%$ & $14.3 \%$ & $18.3 \%$ \\
\hline & Basic life** & 1116 & 903 & 561 \\
\hline & Basic living expenses** & $9.4 \%$ & $6.3 \%$ & $3.7 \%$ \\
\hline \multirow[t]{2}{*}{ Furniture } & Number of generations* & 6209 & 7648 & 7437 \\
\hline & Population per generation** & 1. 98 & 2. 19 & 2.42 \\
\hline \multirow[t]{3}{*}{ Housing } & Percentage of houses less than $60 \mathrm{~m}^{2} * *$ & $57.7 \%$ & $42.4 \%$ & $22.0 \%$ \\
\hline & Housing price $\left(\mathrm{KRW} / \mathrm{m}^{2}\right) * *$ & 261. 0 & 373.3 & 555.4 \\
\hline & Jeonse price $\left(\mathrm{KRW} / \mathrm{m}^{2}\right) * *$ & 169.3 & 265.4 & 387.5 \\
\hline \multicolumn{5}{|c|}{$\begin{array}{l}* * \text { test result was significant at level } a=0.01 \\
* \text { t test result was significant at level } \quad \alpha=0.05\end{array}$} \\
\hline
\end{tabular}


The analysis of the results based on characteristics of the residents in the low-income densely populated Based on the topographical features and site selection characteristics, the areas with dense low-income strata are typified and can be broadly classified into 3 types.

Table 3 Three types of low-income areas

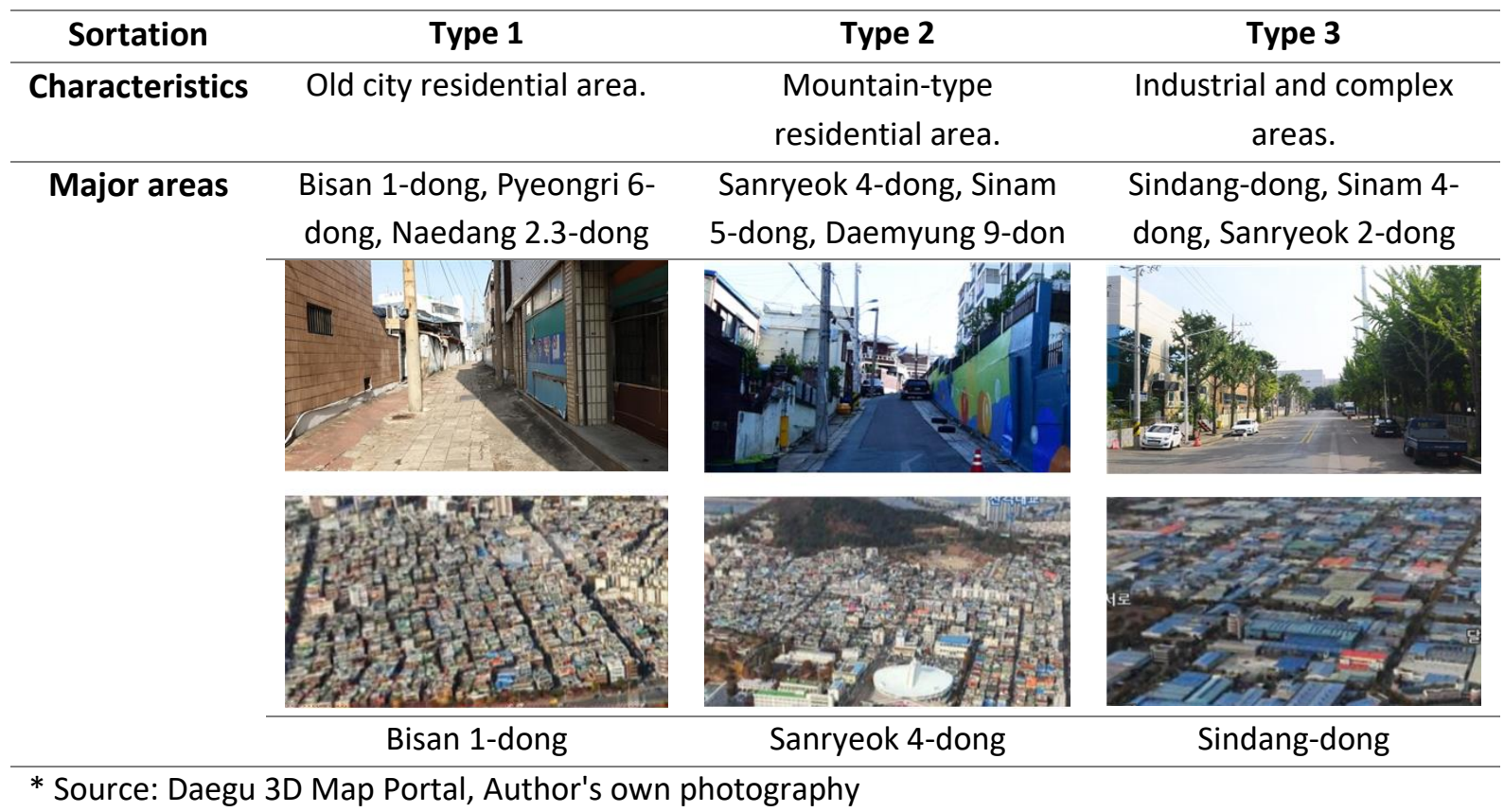

Although Daegu City Government has made efforts to improve the neighborhood environment in areas where socially disadvantaged people live, it has failed to fundamentally address the neighborhood environment in areas where low-income people live. Therefore, to develop an effective and targeted policy, it is necessary to analyze the characteristics of low-income dense areas, the proximity environment, and park characteristics.

\subsection{Analysis of park distribution characteristics}

An empirical study was conducted on the distribution of urban parks, centering on eight autonomous regions and counties in Daegu. According to the survey, the overall park supplies and park area per capita in Daegu city are higher than the legal requirements. The highest ratio of parks was found in the southern district, followed by Suseong-gu, Dalseo-gu, Dalseong-gun. On the contrary, Seo-gu, which has the densest areas of low-income strata, has the lowest park ratio of $3.2 \%$.

In terms of demographic characteristics, there were statistically significant quantitative $(+)$ correlations $(p<0.01)$ between the number of district population, child population ratio, and number of households in park area, park area ratio, and park service area in terms of park distribution. Conversely, there was a negative (-) relationship between the elderly population ratio and park distribution $(p<0.01)$. That is, the higher the population and child population ratios, the more extensive the park area and service area. Conversely, the higher the elderly population ratio, the smaller the park space and service applicability. It is evident that inequality in park distribution still exists at this stage.

The average park space $\left(174,142 \mathrm{~m}^{2}\right)$ and park area $(7.2 \%)$ in the dense areas of the lower-income strata are lower than those with higher-income strata $\left(188,620 \mathrm{~m}^{2}\right.$ and $\left.8.5 \%\right)$. Conversely, park service area, service area per capita ratio, and park area were higher compared to the higher income strata. However, 
in the one-dimensional dispersion analysis, there was no statistically significant difference between the two groups because the $p$-value was greater than 0.05 . The "irrelevant results" presented in Abercrombie et al. (2008) and Maroko et al. (2009) are consistent.

Table 4. Analysis of park distribution characteristics

\begin{tabular}{|c|c|c|c|}
\hline Characteristic indicators & low-income areas. & $\begin{array}{l}\text { The average in } \\
\text { Daegu. }\end{array}$ & High-income areas \\
\hline Park area. & 174,142 & 159,794 & 188,620 \\
\hline The park area ratio. & $7.2 \%$ & $7.3 \%$ & $8.5 \%$ \\
\hline $\begin{array}{c}\text { The scope of the park } \\
\text { service. }\end{array}$ & $1,213,998$ & $1,095,132$ & 783,024 \\
\hline Park service area ratio. & $91.9 \%$ & $87.1 \%$ & $82.1 \%$ \\
\hline Park area per person. & 13.7 & 10.6 & 11.6 \\
\hline $\begin{array}{l}\text { **t test result was signifi } \\
* \text { t test result was signifi }\end{array}$ & $\begin{array}{l}t \text { at level } a=0.01 \\
t \text { at level } a=0.0\end{array}$ & & \\
\hline
\end{tabular}

The distribution of parks in areas with dense low-income strata is related to the slope of the area. Comparing the distribution of various types of parks in areas with dense low-income strata, it appears that the distribution of parks concentrated in the urban center area is the worst. The area around the foothills is mostly surrounded by proximate parks of $30,000 \mathrm{~m}^{2}$ or more. Therefore, the area covered by park services in the region is high. However, the overall distribution of parks within the dense low-income stratum area is the same as in Daegu city, and there are large deviations in the distribution of parks between regions.

Therefore, in the existing urban planning, regional planning, park planning, and policies, in addition to the physical ecological park protection standards, the rationality of park distribution should be considered and priority areas should be designated. In particular, it is difficult to secure land for park construction in dense areas of low-income strata located in old urban areas.

\section{Discussion}

To achieve an inclusive city and improve the living environment of low-income strata, we have acquired the distribution of low-income strata-dense areas. And to improve the living environment of these areas with dense low-income strata through this research, it is necessary to first consider demographic characteristics, living environment, and economic development.

As a result of a survey of low-income areas, the elderly population accounted for more than $20 \%$ of the total population, much higher than other areas. On the other hand, the proportion of children is much lower than the Daegu average. Therefore, a detailed evaluation of the psychological and physical needs of various residents is required. It is also important to ensure fair distribution of open spaces in the region, promote interaction between residents by class, and ease the separation and differentiation of social classes. Based on appropriate social research and analysis, small-scale activity spaces, play spaces, leisure spaces, and social spaces should be designed to meet the diverse spatial needs of the people around them. Currently, there is a big difference in the distribution of parks in Daegu-si and low-income areas. Land use, slope, and residential distribution can all affect the equity of urban parks. The essence of the inequality problem in urban parks is the lack of urban land resources. To solve this problem, it is necessary to simultaneously consider the distribution of equity of resources and maximization of park effects. When constructing or improving a park in a low-income dense area, differences in the physical environment of the park should be considered. Recreation facilities reflecting modern trends and 
regional population characteristics should be installed to improve the physical environment. In areas with a high concentration of the elderly, it is possible to consider building more park sports facilities and convenience facilities suitable for the elderly's park usage habits.

The purpose of this study was to explore the distribution and utilization needs of parks in low-income tier dense areas. However, when extracting low-income stratum dense areas, only materials that could be collected were selected for selection, and although a trustworthiness analysis was done to improve accuracy, more accurate extraction of low-income stratum dense areas could not be performed. Also, only children's parks and near-neighborhood parks located in low-income tier areas were analyzed. Residents using open spaces such as schools, green space buffer areas, and waterfront parks were not considered.

Future research needs to conduct a more in-depth analysis of the physical environmental characteristics of low-income areas. Further research should be conducted on open spaces such as local schools, trails, and green buffer areas, as well as neighborhood environment factors such as transportation environment, walking environment, convenience facilities, and welfare facilities for the elderly. It is more effective in improving the health of low-income families, quality of life, and happiness. In-depth research should be conducted to provide the information necessary to derive effective policies.

\section{Conclusion}

From the perspective of an inclusive city, the park policies and improvement programs are as follows: In terms of policies, the main emphasis is on improving the living environment of low-income groups, the balance of park distribution, and the inclusiveness of park users. In terms of improvement programs, the design and improvement of the physical environment in the area is adapted to the characteristics of the area, and the improvement programs are developed after investigating the characteristics and needs of the local population to further enhance physical health, relieve psychological stress, and promote social interaction.

\section{References}

Abercrombie, L. C., Sallis, J. F., Conway, T. L., Frank, L. D., Saelens, B. E., \& Chapman, J. E. (2008). 'Income and racial disparities in access to public parks and private recreation facilities', American journal of preventive medicine, 34(1), p9-15.

Bedimo-Rung, A. L., Mowen, A. J., \& Cohen, D. A. (2005). 'The significance of parks to physical activity and public health: a conceptual model', American journal of preventive medicine, 28(2), p159-168.

Boone, C. G., Buckley, G. L., Grove, J. M., \& Sister, C. (2009). 'Parks and people: An environmental justice inquiry in Baltimore, Maryland', Annals of the Association of American Geographers, 99(4), p767-787.

Chen, L., Zhang, W. Z. Dong, Y. X. \& Yu, J. H. (2012). 'The spatial distribution, transition and residential pattern of low-income residents in Beijing',GEOGRAPHICAL RESEARCH, 31(4), p720-732.

Cohen, D. A., Han, B., Derose, K. P., Williamson, S., Marsh, T., Rudick, J., \& McKenzie, T. L. (2012). 'Neighborhood poverty, park use, and park-based physical activity in a Southern California city', Social science \& medicine, 75(12),p 2317-2325.

Gordon, C., Purciel-Hill, M., Ghai, N. R., Kaufman, L., Graham, R., \& Van Wye, G. (2011). 'Measuring food deserts in New York City's low-income neighborhoods', Health \& place, 17(2), p696-700.

Gordon-Larsen, Penny, Melissa C. Nelson, Phil Page, \& Barry M. Popkin. (2006). Inequality in the Built Environment Underlies Key Health Disparities in Physical Activity and Obesity, 117(2), p417-424. 
Huang, J. H., Hipp, J. A., Marquet, O., Alberico, C., Fry, D., Mazak, E., ... \& Floyd, M. F. (2020).

'Neighborhood characteristics associated with park use and park-based physical activity among children in low-income diverse neighborhoods in New York City', Preventive medicine, 131, p105948.

Jacobs J.(1961). The death and life of great American cities. New York: Vintage.

Kim, Y. J.(2015). 'Parks equity in metropolitan Seoul for the implementation of green welfare', Seoul National University Graduate School of Environment, Ph.D.

Lakes, T., Brückner, M., \& Krämer, A. (2014). 'Development of an environmental justice index to determine socio-economic disparities of noise pollution and green space in residential areas in Berlin', Journal of Environmental Planning and Management, 57(4), p538-556.

Maroko, A. R., Maantay, J. A., Sohler, N. L., Grady, K. L., \& Arno, P. S. (2009). 'The complexities of measuring access to parks and physical activity sites in New York City: a quantitative and qualitative approach', International journal of health geographics, 8(1), p1-23.

Orsega-Smith, E., Mowen, A. J., Payne, L. L., \& Godbey, G. (2004). 'The interaction of stress and park use on psycho-physiological health in older adults', Journal of Leisure Research, 36(2), p232-256.

Park, J. H., Chung, H.(2019). 'Socio-spatial Change from Exclusion to Inclusion of Minorities: A Case Study on Visually Impaired Diviners in Dongseon-dong, Seoul', Journal of the Korean Urban Geographical, 22(1), p111-129.

Rigolon, A. 2017. 'Parks and Young People: An Environmental Justice Study of Park Proximity, Acreage, and Quality in Denver, Colorado', Landscape and Urban Planning 165, p73-83.

Schipperijn, J., Cerin, E., Adams, M. A., Reis, R., Smith, G., Cain, K., ... \& Sallis, J. F. (2017). 'Access to parks and physical activity: an eight country comparison', Urban forestry \& urban greening, 27, p253-263.

Sundquist, K., Malmström, M., \& Johansson, S. E. (2004). 'Neighbourhood deprivation and incidence of coronary heart disease: a multilevel study of 2.6 million women and men in Sweden', Journal of epidemiology and community health, 58(1), p71-77.

UN-HABITAT3 (2016a). Policy Paper No.1: Right to the City and Cities for All.

Wen, M., Zhang, X., Harris, C. D., Holt, J. B., \& Croft, J. B. (2013). 'Spatial disparities in the distribution of parks and green spaces in the USA', Annals of Behavioral Medicine, 45(suppl_1), pS18-S27. 